\section{Peningkatan Kualitas Proses dan Hasil Belajar Biologi dengan Experiental Learning Siswa Kelas X MIPA 7 SMA Negeri 1 Makassar}

\author{
Abdul Hajar
}

Abstrak. Tercapainya proses belajar mengajar yang efektif tidak mungkin hanya dengan metode yang bersifat teacher centered atau komunikasi satu arah, akan tetapi harus juga dengan metode yang bersifat multiarah atau student centered. Penelitian bertujuan untuk mengetahui peningkatan kualitas proses dan hasil belajar siswa dengan experiental learning pada mata pelajaran biologi. Penelitian merupakan penelitian tindakan kelas, sebagai salah satu alternatif upaya yang dapat dilakukan oleh guru untuk mengembangkan dan meningkatkan kualitas pembelajaran, dimana guru kelas adalah pelaku tindakan atau guru sebagai peneliti. Penelitian ini merupakan pengkajian berdaur (cyclical) yang terdiri dari 4 tahap, yaitu: merencanakan, melakukan tindakan, observasi dan merefleksi. Penelitian ini dilaksanakan pada kelas X MIPA 7 di SMA Negeri 1 Makassar, dengan subjek penelitian sebanyak 34 siswa, pada semester genap tahun ajaran 2018/2019. Hasil penelitian menunjukkan bahwa proses dan hasil belajar biologi dapat ditingkatkan dengan menggunakan experiental learning pada siswa kelas X MIPA 7 SMA Negeri 1 Makassar.

Kata Kunci: proses dan hasil belajar, experiental learning

\section{Pendahuluan}

Kemajuan dalam bidang pendidikan hanya dapat tercapai jika dilakukan pembenahan proses belajar mengajar. Tercapainya proses belajar mengajar yang efektif tidak mungkin hanya dengan metode yang bersifat teacher centered atau komunikasi satu arah, akan tetapi harus juga dengan metode yang bersifat multi arah atau student centered.

Pembelajaran yang dilakukan di kelas kadangkala menyebabkan siswa pasif hanya sekedar menerima apa saja yang disampaikan oleh guru. Hal ini dapat menyebabkan rendahnya kualitas pembelajaran di sekolah. Kelemahan tersebut dapat diatasi antara lain dengan cara memperbaiki metode pembelajaran di kelas atau melaksanakan pembelajaran di luar kelas sesuai dengan karakter materi pembelajaran. Faktor yang sangat mempengaruhi tugas utama guru dalam membantu siswa belajar adalah dengan skenario pembelajaran yang sering dipilihnya selama proses belajar berlangsung (Iskandar, 2001). Seperti halnya siswa kelas X MIPA 7, kelas ini terletak pada bagian belakang sekolah, dan bersebelahan dengan kantin, sehingga dapat mengganggu konsentrasi belajar siswa. Kelas ini terdiri dari siswa yang heterogen. Hasil pengamatan selama peneliti mengajar selama ini, menunjukkan prestasi belajar siswa yang belum

\section{Biology Teaching \\ and Learning}

\author{
p-ISSN 2621 - 5527 \\ e-ISSN 2621 - 5535
}

Abstract. Achieving effective teaching and learning is not possible only with methods that are teacher centered or oneway communication, but must also be a method that is multi-purpose or student centered. The study aims to determine the improvement of the quality of the process and student learning outcomes with experiential learning on biology subjects. Research is a class action research, as an alternative effort that can be done by teachers to develop and improve the quality of learning, where classroom teachers are actors of action or teachers as researchers. This research is a cyclical study consisting of 4 stages, namely:

planning, taking action, observing and reflecting. This research was conducted in class X MIPA 7 in Makassar 1 Public High School, with 34 subjects as subjects, in the even semester 2018/2019 academic year.

The results showed that the process and results of learning biology can be improved by using experiential learning in class X MIPA 7 Makassar 1 Public High School.

Keywords: learning processes and results, experiential learning

Abdul Hajar
SMA Negeri 1 Makassar
Indonesia


Siswa belajar seadanya tanpa termotivasi untuk meningkatkan proses dan hasil belajaranya, sehingga dapat mempengaruhi suasana kelas. Olehnya itu diperlukan strategi khusus untuk meningkatkan kualitas proses pembelajaran, khususnya yang berkaitan dengan materi ekosistem dan materi-materi yang berkaitan dengan ekologi.

Salah satu strategi yang dapat diterapkan dalam pembelajaran biologi serta diharapkan dapat mengubah cara belajar siswa dari "rote learning" ke dalam cara belajar bermakna (meaningful learning) adalah dengan menyusun kembali struktur kognitif siswa dengan experiental learning. Banyak pakar pendidikan berpendapat bahwa proses dan hasil belajar akan banyak ditentukan atau dipengaruhi oleh pengetahuan awal yang telah dimiliki oleh siswa kemudian merelevansikannya dengan struktur kognitif yang akan diperolehnya.

Experiental learning yang dapat merancang model ekosistem buatan yang diatur dengan memasukkan unsur biotik dan unsur abiotik. Model aquarium berseri ini akan menunjukkan miniatur ekosistem yang lebih luas dan dapat menjawab permasalahan lingkungan. Dengan melakukan observasi siswa berusaha mencocokkan konsep-konsep sebagai teori dengan apa yang dapat diamati di lingkungannya. Oleh karena dengan pembelajaran yang berlangsung secara terus menerus atau berulang-ulang maka dalam waktu yang lama (long term memory), akan tersimpan sebagai konsep yang resistensi. Penerapan strategi ini didasarkan pada teori belajar kognitif, pendekatan konstruktif dan pembelajaran berbasis pengalaman. Sehingga kualitas pembelajaran dapat ditingkatkan, baik kualitas proses pembelajaran dengan interaksi edukatif yang dioptimalkan maupun kualitas hasil pembelajaran.

Experiental learning merupakan salah satu strategi yang dapat dipilih dan diterapkan dalam pembelajaran biologi serta diharapkan dapat mengubah cara belajar siswa dari "rote learning" ke dalam cara belajar bermakna (meaningful learning). Cara yang dapat dilakukan adalah dengan menyusun kembali struktur kognitif siswa dengan experiental learning. Banyak pakar pendidikan berpendapat bahwa proses dan hasil belajar akan banyak ditentukan atau dipengaruhi oleh pengetahuan awal yang telah dimiliki oleh siswa kemudian merelevansikannya dengan struktur kognitif yang akan diperolehnya. Dengan melakukan observasi siswa berusaha mencocokkan konsep-konsep sebagai teori dengan apa yang dapat diamati di lingkungannya. Oleh karena dengan pembelajaran yang berlangsung secara terus menerus atau berulang-ulang maka dalam waktu yang lama (long term memory), akan tersimpan sebagai konsep yang resistensi. Penerapan strategi ini didasarkan pada teori belajar kognitif, pendekatan konstruktif dan pembelajaran berbasis pengalaman.

Experiental learning merupakan bentuk pembelajaran yang dikembangkan berdasarkan pengajaran berbasis pengalaman. Tujuan pembelajaran ini adalah: (1) menambah rasa percaya diri dan kemampuan pelajar melalui partisipasi aktif, dan (2) menciptakan interaksi sosial yang positif guna memperbaiki hubungan sosial dalam kelas. Pembelajaran ini dilandasi oleh prinsip belajar sambil berbuat (learning by doing) (Hamalik, 2001).

\section{Metode Penelitian}

\section{Latar Belakang Umum Penelitinan}

Penelitian ini merupakan Penelitian Tindakan Kelas (PTK), sebagai salah satu alternatif upaya yang dapat dilakukan oleh guru untuk mengembangkan dan meningkatkan kualitas pembelajaran. Dimana guru kelas adalah pelaku tindakan atau guru berperan sebagai peneliti (Depdiknas, 2002). PTK dilaksanakan berupa proses pengkajian berdaur (cyclical) yang terdiri dari 4 tahap yaitu merencanakan, melakukan tindakan, observasi dan merefleksi.

Rincian kegiatan adalah sebagai berikut: (1) perencanaan: mengkaji kompetensi dasar, indikator pencapaian, mengkaji silabus, rencana pelaksanaan pembelajaran dan sistem penilaian, menentukan KKM yaitu 79, (2) pelaksanaan tindakan (action): menerapkan model pembelajaran experiental learning, untuk masing-masing siklus, (3) observasi: mengamati dan 
Peningkatan Kualitas Proses dan Hasil Belajar Biologi

dengan Experiental Learning Siswa Kelas X MIPA 7

p-ISSN 2621-5527

SMA Negeri 1 Makassar

e-ISSN 2621-5535

(hlm. 55-61)

mencatat jalannya proses pembelajaran dengan menggunakan lembar observasi yang telah disiapkan, dan (4) refleksi dan evaluasi: hasil pengamatan dianalisis serta dilakukan evaluasi terhadap proses dan hasil pembelajaran.

\section{Waktu dan Tempat Penelitian}

Penelitian ini dilaksanakan di SMA Negeri 1 Makassar, dengan subjek penelitian adalah siswa kelas X MIPA 7, pada semester genap tahun pelajaran 2018/2019. Pemilihan kelas X MIPA 7 , mengingat kelas ini merupakan salah kelas paralel di kelas $X$, yang siswa sangat heterogen, yang dibina langsung oleh peneliti. Pengalaman peneliti selama mengajar di kelas ini masih membutuhkan penanganan yang sungguh-sungguh. Kelas ini merupakan kelas dengan suasana kelas belum menunjukkan semangat untuk mengikuti proses pembelajaran dengan baik.

\section{Prosedur Penelitian}

Penelitian tindakan kelas ini dilaksanakan dalam 2 (dua) siklus. Pelaksanaan siklus ini mempertimbangkan jumlah tatap muka yang telah direncanakan oleh guru mata pelajaran yang bersangkutan.

\section{Siklus I}

Siklus ini dilaksanakan selama 3 (tiga) minggu, yakni sebanyak 2 (dua) kali pertemuan tatap muka dan satu kali pertemuan dengan ulangan harian untuk mengetahui kualitas proses dan hasil pembelajaran. Adapun tahapannya sebagai berikut:

\section{a. Perencanaan Tindakan}

mempelajari dengan cermat bahan pelajaran yang akan diajarkan, (2) menyiapkan bahan pelajaran diolah sehingga ditemukan suatu konsep-konsep yang diharapkan akan dapat dipelajari oleh siswa, (3) membuat skenario pembelajaran yang memfokuskan kompetensi dasar yang akan dicapai dan pada keaktifan siswa berdasarkan tujuan pembelajaran; (4) menyiapkan sarana pendukung yang diperlukan selama proses belajar mengajar berlangsung; dan (5) membuat pedoman observasi dan lembar pengamatan.

\section{b. Pelaksanaan Tindakan}

Tahap ini merupakan tahap inti penelitian dan merupakan kegiatan proses belajar mengajar sesuai dengan skenario yang telah disusun, yang menonjolkan tindakan yang ingin dicapai, yaitu mengkonstruksi kembali struktur kognitif siswa dengan experiental learning, antara lain melalui kegiatan, apersepsi dan pemberian pengalaman langsung. Adapun gambaran umum kegiatan-kegiatan pembelajaran yang akan dilakukan adalah:

1) Pada awal kegiatan pembelajaran, guru memberikan materi prasyarat yang diperlukan sehubungan dengan pokok bahasan yang akan diajarkan.

2) Guru memberikan penjelasan mengenai materi pembelajaran dan tujuan yang akan dicapai setelah proses belajar mengajar.

3) Siswa diberi kesempatan untuk menemukan sendiri konsep-konsep selama pembelajaran baik dari hasil bacaan maupun dari penjelasan guru.

4) Konsep-konsep yang ditemukan oleh siswa, disesuaikan dengan hasil pengamatan secara langsung dari hasil pembelajaran dengan experiental learning

5) Siswa diminta menyesuaikan konsep-konsep teori yang diperolehnya di kelas dengan hasil pengamatannya. Dalam melakukan aktivitas ini siswa diatur secara berkelompok;

6) Siswa diminta memberikan kesimpulan hasil belajar berdasarkan penemuannya setelah melakukan diskusi

7) Guru melengkapi kesimpulan siswa, jika kesimpulan yang diberikan oleh siswa kurang jelas.

\section{c. Observasi dan Evaluasi}

Selama proses pembelajaran akan diadakan pengamatan tentang: 
p-ISSN 2621-5527

e-ISSN 2621-5535
Peningkatan Kualitas Proses dan Hasil Belajar Biologi dengan Experiental Learning Siswa Kelas X MIPA 7

SMA Negeri 1 Makassar

(hlm. 55-61)

1) Sikap siswa mengikuti pelajaran

2) Keaktifan siswa mengikuti pembelajaran

3) Kemampuan siswa memberikan penjelasan tentang konsep yang diperolehnya dari kajian teori dan hasil pengamatan secara langsung.

4) Kemampuan siswa memberikan tanggapan terhadap konsep yang ditemukan.

5) Untuk mendapatkan informasi balikan dari siswa tentang kegiatan pembelajaran yang telah dilakukan maka pada akhir siklus ini akan diedarkan lembaran kuesioner.

6) Hasil tindakan juga dievaluasi dengan memberikan tes yang berfungsi sebagai ulangan harian.

\section{d. Refleksi}

Hasil observasi dan evaluasi akan dianalisis untuk dijadikan bahan pemikiran dalam merefleksi kegiatan selama tindakan dilakukan. pada tahap ini dilihat sampai dimana keberhasilan tindakan yang telah dilakukan. Hal-hal yang masih dipandang kurang akan ditindaki pada siklus berikutnya dengan suatu model tindakan ke arah yang lebih baik sehingga keaktifan dan pencapaian konsep akan lebih meningkat.

2. Siklus II

Siklus ini dilaksanakan selama 3 (tiga) minggu atau 3 (tiga) kali pertemuan. 2 (dua) kali pertemuan dilakukan untuk kegiatan pembelajaran tatap muka dan satu kali pertemuan untuk kegiatan ulangan harian. Kegiatan ini dilakukan untuk mengetahui kualitas proses dan hasil pembelajaran Pada siklus ini akan dilakukan langkah-langkah yang relatif sama pada siklus pertama dengan beberapa perbaikan berdasarkan hasil refleksi siklus pertama.

Data yang dikumpulkan akan dianalisis secara kualitatif dan kuantitatif. Data hasil observasi, kuesioner dan catatan harian akan dianalisis secara kualitatif. Data hasil belajar dianalisis secara kuantitatif dengan menggunakan statistik deskriptif. Peningkatan kualitas proses dan hasil pembelajaran diketahui dengan memperhatikan indikator kinerja keaktifan siswa selama mengikuti pembelajaran dan peningkatan hasil belajar siswa adalah dengan melihat pencapaian Kriteria Ketuntasan Minimal (KKM) yang telah ditentukan yaitu sebesar 79 dalam dua kali tes setiap siklusnya.

\section{Hasil dan Pembahasan}

\section{Hasil Penelitian}

\section{Gambaran Umum Siklus I}

Hasil analisis deskriptif data hasil belajar biologi siswa kelas X MIPA 7 SMA Negeri 1 Makassar berdasarkan hasil tes yang dilakukan pada akhir siklus I dirangkum pada tabel berikut:

Tabel 1. Statistik Skor Hasil Belajar Biologi Siswa pada Akhir Siklus I

\begin{tabular}{|c|c|}
\hline Statistik & Nilai Statistik \\
\hline Banyaknya subyek penelitian & 34 \\
\hline Skor rata-rata & 75,25 \\
\hline Standar deviasi & 9,470 \\
\hline Skor maksimum & 95 \\
\hline Skor minimum & 60 \\
\hline
\end{tabular}


Peningkatan Kualitas Proses dan Hasil Belajar Biologi dengan Experiental Learning Siswa Kelas X MIPA 7

(hlm. 55-61)

Dari tabel 1 di atas menunjukkan bahwa secara klasikal tingkat penguasaan siswa pada siklus pertama adalah sebesar $75,25 \%$. Sedangkan secara perorangan tingkat penguasaan siswa bergerak dari $60 \%$ sampai dengan $95 \%$.

\section{Gambaran Umum Siklus II}

Hasil analisis deskriptif data hasil belajar biologi siswa kelas X MIPA 7 SMA Negeri 1 Makassar berdasarkan hasil tes yang dilakukan pada akhir siklus II dirangkum pada tabel berikut:

Tabel 2. Statistik Skor Hasil Belajar Biologi Siswa pada Akhir Siklus II

\begin{tabular}{|c|c|}
\hline Statistik & Nilai statistik \\
\hline Banyaknya subyek penelitian & 34 \\
\hline Skor rata-rata & 79,00 \\
\hline Standar deviasi & 7,525 \\
\hline Skor maksimum & 95 \\
\hline Skor minimum & 65 \\
\hline
\end{tabular}

Dari tabel 2 di atas menunjukkan bahwa secara klasikal tingkat penguasaan siswa pada siklus kedua adalah sebesar $79,00 \%$. Sedangkan secara perorangan tingkat penguasaan siswa bergerak dari $65 \%$ sampai dengan $95 \%$.

\section{Komparasi Deskriptif untuk Kedua Siklus}

Rata-rata skor hasil belajar biologi berdasarkan hasil analisis deskriptif data hasil belajar biologi siswa kelas X MIPA 7 SMA Negeri 1 Makassar untuk kedua siklus dirangkum pada tabel berikut:

Tabel 3. Rata-Rata (mean) Hasil Belajar Biologi untuk Setiap Siklus.

\begin{tabular}{|l|l|}
\hline Siklus Penelitian & Rata-rata (mean) \\
\hline Siklus Pertama & 75,25 \\
\hline Siklus Kedua & 79,00 \\
\hline
\end{tabular}

Dari tabel 3 di atas menunjukkan adanya peningkatan rata-rata (mean) skor hasil belajar biologi dari siklus pertama 75,25 ke siklus kedua 79,00. Dengan demikian dapat dikatakan bahwa hasil belajar biologi siswa kelas X MIPA 7 SMA Negeri 1 Makassar dapat ditingkatkan melalui experiental learning. Pada materi komponen ekosistem, hubungan antar komponen, keseimbangan antar komponen dan aliran energi, daur biogeokimia maupun suksesi.

\section{Pembahasan}

Dari data hasil penelitian diketahui bahwa dari hasil siklus pertama dan siklus kedua nilai tertinggi yang dicapai oleh siswa sebesar 95. Skor rata-rata mengalami peningkatan dari 75,25 menjadi 79,00. sedangkan skor minimum juga mengalami peningkatan dari 60 menjadi 65. Ini menunjukkan kemampuan siswa atau daya serap siswa dalam mengikuti proses belajar mengajar mengalami peningkatan. Hal ini dapat disebabkan oleh penggunaan experiental learning pada materi komponen ekosistem, hubungan antar komponen, keseimbangan antar komponen dan aliran energi, daur biogeokimia maupun suksesi siswa kelas X MIPA 7 SMA Negeri 1 Makassar. Ini berarti bahwa pembelajaran dengan experiental learning pada materi komponen ekosistem, hubungan antar komponen, keseimbangan antar komponen dan aliran 
energi, daur biogeokimia maupun suksesi dapat meningkatkan keberhasilan siswa dalam belajarnya dalam arti bahwa siswa dapat lebih mudah mengerti dan memahami serta dapat menguasai materi.

Jumlah siswa yang mencapai ketuntasan dalam belajar, menunjukkan bahwa dengan experiental learning pada materi komponen ekosistem, hubungan antar komponen, keseimbangan antar komponen dan aliran energi, daur biogeokimia maupun suksesi, belajar siswa dan hasil belajar siswa akan lebih bermakna. Hal ini berarti bahwa dengan experiental learning pada materi komponen ekosistem, hubungan antar komponen, keseimbangan antar komponen dan aliran energi, daur biogeokimia maupun suksesi dapat meningkatkan kebermaknaan dalam belajar. Dalam arti bahwa belajar bermakna akan dipertahankan bila dalam struktur kognitif semua konsep-konsep saling kait mengait. Belajar bermakna memperlihatkan hubungan antara konsep-konsep yang penting (Dahar, 1989). Dengan pembelajaran dengan experiental learning pada materi komponen ekosistem, hubungan antar komponen, keseimbangan antar komponen dan aliran energi, daur biogeokimia maupun suksesi dapat membandingkan adanya penegasan makna dan kejelasan arti, siswa dapat melihat secara langsung atau mengadakan pengamatan, bahwa ekosistem yang diamatinya dapat memberikan pemahaman yang lebih luas di alam. Siswa dapat mengetahui bagaimana interaksi makhluk hidup dengan komponen lainnya dengan memperhatikan aquarium berseri yang menunjukkan adanya interaksi antar komponen di dalam sebuah ekosistem, sehingga siswa dapat memahami dengan mudah materi yang pelajaran yang dimaksud. Pokok bahasan tertentu akan lebih jelas dalam mempelajarinya serta lebih bermakna, siswa dapat menyimpan pengetahuannya lebih lama.

Hal ini sejalan dengan penegasan Nasution (1989) yang menyatakan bahwa dengan pembelajaran dengan menggunakan berbagai strategi seperti halnya dengan experiental learning pada materi komponen ekosistem, hubungan antar komponen, keseimbangan antar komponen dan aliran energi, daur biogeokimia maupun suksesi dapat meningkatkan minat dan motivasi belajar siswa sehingga dapat meningkatkan penguasan materi serta konsep-konsep mendasar dari suatu pokok bahasan. Penegasan ini didukung dengan hasil observasi selama berlangsungnya proses pembelajaran dan tanggapan siswa terhadap pembelajaran dengan experiental learning pada materi komponen ekosistem, hubungan antar komponen, keseimbangan antar komponen dan aliran energi, daur biogeokimia maupun suksesi dapat menambah motivasi belajar siswa, mempermudah belajar, dapat menarik siswa untuk belajar, menambah kualitas belajar dan meningkatkan minat belajar siswa.

Dengan demikian, dapat dijelaskan bahwa dengan experiental learning, guru dapat mengajar dengan baik dan profesional, Guru dapat meningkatkan kualitas proses dan hasil belajar dengan experiental learning. Strategi experiental learning, dapat menambah rasa percaya diri bagi siswa untuk berpartisipasi aktif dan menciptakan hubungan sosial dalam kelas (Hamalik, 2001).

\section{Kesimpulan}

Berdasarkan hasil penelitian, dapat ditarik kesimpulan bahwa (1) Penggunaan experiental learning pada materi komponen ekosistem, hubungan antar komponen, keseimbangan antar komponen dan aliran energi, daur biogeokimia maupun suksesi dalam proses pembelajaran dapat meningkatkan kualitas proses dan hasil belajar siswa kelas X MIPA 7 SMA Negeri 1 Makassar.

Berdasarkan hasil penelitian yang diperoleh, maka disarankan: (1) Pembelajaran dengan experiental learning perlu dikembangkan lebih optimal disesuaikan dengan ketersediaan alat atau sumber belajar yang ada di sekolah, (2) Pembelajaran dengan experiental learning perlu disosialisasikan pada guru-guru mata pelajaran biologi pada sekolah-sekolah lainnya. Sebagai salah satu bentuk strategi dalam meningkatkan kebermaknaan dalam belajar. 
Peningkatan Kualitas Proses dan Hasil Belajar Biologi

dengan Experiental Learning Siswa Kelas X MIPA 7

p-ISSN 2621-5527

SMA Negeri 1 Makassar

e-ISSN 2621-5535

(hlm. 55-61)

\section{Referensi}

Dahar, R.W. (1989). Teori-teori Belajar. Jakarta. Erlangga.

Depdiknas. (2007). Pedoman Blockgrant Penelitian Tindakan Kelas. Jakarta: Direktorat Jenderal Peningkatan Mutu Pendidik dan Tenaga Kependidikan Direktorat Profesi Pendidik.

Hamalik, O. (1999). Kurikulum dan Pembelajaran. Jakarta. Bumi Aksara.

Indrawati. (2008). Penelitian Tindakan Kelas. Bandung: Pusat Pengembangan dan Pemberdayaan Pendidik dan Tenaga Kependidikan Ilmu Pengetahuan Alam.

Iskandar, S.M. (2001). Penerapan Konstruktivisme dalam Pembelajaran Kimia di SMU. Media Kemunikasi Kimia, 5 (2).

Kemendikbud. (2016). Pedoman Mata Pelajaran SMA, Biologi, Jakarta.

Kemendikbud. (2016). Silabus Mata Pelajaran, SMA, Biologi, Jakarta.

Nasution. (1999). Kurikulum dan Pengajaran. Jakarta. Bumi Aksara.

Slameto. (1995). Belajar dan Faktor-faktor yang Mempengaruhinya. Yogyakarta: Rineka Cipta.

Tim Pelatih Proyek PGSM. (1999). Penelitian Tindakan Kelas (Classroom Research). Depdikbud Dirjen Dikti PGSM.

Umar. (2006). Penelitian Tindakan Kelas (PTK). Bahan Diklat. Jakarta. Depdiknas Dirjen Peningkatan Mutu Pendidik dan tenaga Kependidikan Direktorat Pembinaan Pendidikan dan Pelatihan.

\begin{tabular}{|l|l|}
\hline Abdul Hajar & $\begin{array}{l}\text { SMA Negeri 1 Makassar } \\
\text { Email: harsmaga@yahoo.com }\end{array}$ \\
\hline
\end{tabular}

